\section{The growth of a Taiwanese Buddhist association in China: Soft power and institutional learning}

\author{
André Laliberté \\ University of Ottawa, Canada
}

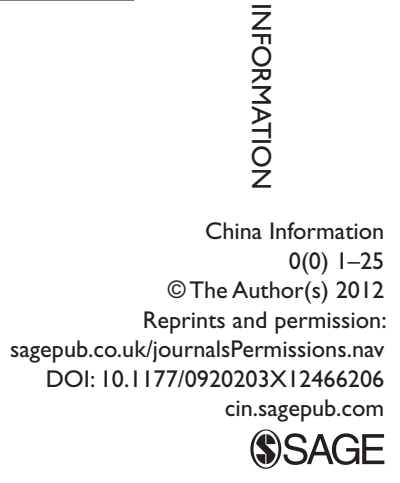

@SAGE

\begin{abstract}
This article looks at Ciji, a Taiwanese Buddhist charity which has been active in China since 1991. Ciji's presence in China is all the more remarkable in view of outbreaks of crises in relations across the Taiwan Strait as well as the religious nature of the organization. The article first addresses the issue of Taiwan's soft power in its relations with China and suggests the possibility that Cijis activities in Taiwan have shown China the benefits of a liberal policy towards religion in that charitable activities carried out by religious organizations complement the government's social policies. The second section chronicles Ciji's presence in China since 199I and shows that local governments have their own reasons for welcoming Ciji's volunteers. The third section compares and contrasts state approaches in China and Taiwan with respect to the provision of social services by religious organizations and notes that even if local governments in China are learning about the benefits of a more open policy in their dealings with Ciji, the central government has not adopted the liberal approach of the Taiwanese government in the regulation of religion.
\end{abstract}

\title{
Keywords
}

Buddhist philanthropy, cross-Strait relations, local governance, social policy, soft power, state regulation of religion

This article looks at the largest philanthropic organization in Taiwan, the Buddhist Compassion Relief Tzu Chi Foundation (佛教慈濟慈善事業基金會, hereafter Ciji). ${ }^{1}$ In March 2008 it registered with Chinese authorities - the first transnational organization headed by a Taiwanese national to do so. ${ }^{2}$ This is remarkable for a number of

\footnotetext{
Corresponding author:

André Laliberté, School of Political Studies, University of Ottawa, 120 University, Ottawa, Ontario KIN 6N5, Canada

Email:Andre.Laliberte@uottawa.ca
} 
reasons. Ciji is a charity organization founded by a Buddhist nun, Cheng Yen (Zhengyan), and is known in Taiwan for its involvement in health care and education, ${ }^{3}$ which are two domains that have been under state control and off-limits to religious institutions in the People's Republic of China (PRC) since 1949. ${ }^{4}$ Ciji's registration in 2008 formally institutionalized the status of a Taiwanese religious organization whose volunteers have visited almost all of China's provinces in the last two decades despite outbreaks of crises between Beijing and Taipei. Ciji's high profile makes it a major asset that enhances Taiwan's soft power, thereby raising questions about whether we should interpret Ciji's presence in the PRC as indicative of the Chinese authorities' interest in Taiwan's norms of governance of religious affairs. In other words, have Ciji's achievements in Taiwan demonstrated to Chinese authorities that there could be some lessons to be learnt from Taiwan's approach to religions and their organizations, namely involving them in the provision of social services? This question about institutional learning deserves serious consideration in light of the Chinese Communist Party's (CCP) treatment of religions in China, the predicaments of its social policies, and the uncertainties in cross-Strait relations despite the re-election of Ma Ying-jeou as president of Taiwan, for whom the CCP has an outspoken preference.

The article is organized as follows. First, it briefly addresses the issue of soft power, Taiwan's trump card in its relations with China, as the latter becomes the more powerful of the two in terms of military and economic strength. The article then chronicles Ciji's presence in the PRC within the broader context of cross-Strait relations. It describes the expansion of its presence in China and explores the extent to which we can delink that expansion with the state of cross-Strait relations; that is, to what extent is Ciji accepted in China despite tensions between Beijing and Taipei? The article discusses the local context of governance at the provincial and county level with respect to the provision of relief and the delivery of social services, and it seeks to show that the interests and concerns of local governments about the provision of social services are independent of the vicissitudes of cross-Strait relations. Finally, the third section briefly contrasts the initial approaches of the Republic of China (ROC) and the PRC with regard to the provision of social services by religious actors. It also poses the question of whether we are seeing signs of a convergence in the PRC towards the approach adopted in the ROC.

\section{Taiwan's 'soft power'}

Where Beijing is concerned, the re-election of Ma Ying-jeou has not put to rest all uncertainties in cross-Strait relations. In the eyes of the CCP, there is always the possibility that the Taiwanese may support a party opposing the agenda of reunification in the next election in 2016, thereby bringing back uncertainties. ${ }^{5}$ The Taiwanese on their part are made to realize the need to gain support from the international community. ${ }^{6}$ In the context of China's rise in economic and military terms, Taiwan is aware that it can no longer use its economic prowess as leverage, ${ }^{7}$ especially as the 'Beijing consensus' is gaining popularity among critics of the neo-liberal Washington consensus. ${ }^{8}$ Nor can Taiwan expect its armed forces to deter the People's Liberation Army from launching an attack on Taiwan. ${ }^{9}$ Finally, China's continued efforts to exclude Taiwan from participation in 
international organizations whose membership is open only to sovereign states make Cf vulnerable on the diplomatic front. ${ }^{10}$ And yet Taiwan holds a trump card that helps it friends in the international community and among Chinese citizens: its soft power, embodied in its democratic political system and its civil society. ${ }^{11}$

Nye defined 'soft power' as 'the ability to shape what others want by being attractive'. ${ }^{12} \mathrm{He}$ argued that soft power is inherent in the attractiveness of a country's culture, its political and social values, as well as its foreign policy. ${ }^{13}$ International relations specialists in China and Taiwan have adopted this concept but given it different meanings. ${ }^{14}$ As Delisle noted, Chinese intellectuals and policymakers emphasize the use of 'soft power' to allay the anxieties of foreigners about the rise of China, ${ }^{15}$ while their Taiwanese counterparts use it in a more defensive manner to attract and ensure US support. ${ }^{16}$ In this article I follow the Taiwanese definition of the concept as understood and formulated by its leaders and international relations experts, which is 'the ability to change others' preferences through persuasion'. ${ }^{17}$ Although for many decades Taiwan has had the ability to deter aggression from China, the growth of the PRC's economy and size of its military budget make it increasingly difficult for Taiwan to sustain that position. ${ }^{18}$ In that context, Taiwan must rely on other resources, such as its economic prowess, culture, ideology, and values to gain the support of other countries. ${ }^{19}$

In a discussion on the concept of soft power by Chinese and Taiwanese scholars, Wang and $\mathrm{Lu}$ note that Chinese definitions of soft power are more encompassing than Nye's original articulation of the concept ${ }^{20}$ including not only appeals to culture, domestic institutions, and diplomacy but also attributes such as internal coherence, and a dimension that is intangible, immaterial, or spiritual described as 'the ability to ... convince others with moral principles'. ${ }^{21}$ Wang and Lu also stress that Chinese authorities rely on traditional Chinese culture as a means to attract others and that they use their economic success as a development model..$^{22}$ Taiwanese definitions of soft power, often used by practitioners, also stress the importance of culture, values, and economic success. But Wang and $\mathrm{Lu}$ note that Taiwanese people regard democracy as the greatest source of attraction to Westerners and like-minded democracies. ${ }^{23}$ Keeping in mind the particular political culture of the PRC and the differences in the concept of soft power held by both countries, how is Taiwanese soft power perceived in China? Because of their interactions and shared cultural references, the differences between Chinese and Taiwanese are not irreconcilable and the gap between them can be bridged conceptually.

Both the Chinese and Taiwanese governments rely on diplomacy for the deployment of soft power in their dealings with other states and international organizations. However, the current stalemate in bilateral relations between China and Taiwan makes informality and person-to-person contacts all the more relevant. ${ }^{24} \mathrm{In}$ this respect, Taiwan's civil society and participation in international non-governmental organization (NGO) networks are major assets. This contrasts with China, which, despite some progress in the growth of NGOs in the country, ${ }^{25}$ continues to prevent the emergence of associations that are truly independent. ${ }^{26}$ Wang and $\mathrm{Lu}$ note that the reputation of Taiwanese international NGOs is one aspect of Taiwan's soft power and that these international NGOs could enhance Taiwan's appeal in the international community. ${ }^{27}$ However, the authors do not make the case that this could also matter in cross-Strait relations. This article sets out to establish whether Taiwanese civil society organizations in China represent a vital source 
of soft power. It also examines the extent to which public goods that such organizations provide in China could be seen as an expression of Taiwan's soft power, and whether some of the bad feelings arising from political tensions as well as labour disputes involving Taiwanese business enterprises can be offset. The article raises the possibility that benevolence as embodied by Taiwanese volunteers in China could change perceptions in cross-Strait relations.

Ciji is seen as one of the major expressions of Taiwan's soft power. But this reality needs to be qualified. First, Ciji is not the only Taiwanese NGO working in China. Nor is it the only Taiwanese Buddhist organization active there. However, it is the most important Taiwanese NGO, and its presence in China is more important than that of the other main Taiwanese Buddhist association, the Buddha Light International Association, in terms of activities such as disaster relief. Second, the presence of Ciji in China has been made possible thanks to its human resources and capacity as a transnational organization. Although Ciji is headquartered in Taiwan, an important source of its support also comes from its overseas branches in Malaysia and the Philippines, the United States and Canada, as well as South Africa and Australia, all of which enjoy a high membership. ${ }^{28}$ Third, Ciji does not work on behalf of Taiwanese authorities, even though its achievements in Taiwan, overseas, and in China, meet the objectives of successive Taiwanese governments, which include improving social welfare in Taiwanese society, promoting within the international community an image of Taiwan as a compassionate society, and generating goodwill in cross-Strait relations. Finally, Ciji is an organization with a hybrid identity. It is a genuine religious association led by a Buddhist nun, whose members are clearly devoted to her, but at the same time, it must downplay this aspect of its identity when it carries out its work in China. ${ }^{29}$ Even in Taiwan, Ciji is not registered as a religious organization.

The presence of Ciji in China can work to the advantage of the Chinese government in a number of ways. Politically, as the next section demonstrates, Ciji is an organization that refuses to be involved in politics, but at the same time it maintains very cordial relations with ruling authorities. Ciji's conformity to existing laws and regulations in Taiwan and China could be read as an expression of support for political authorities in both countries. Chinese authorities' acceptance of Ciji contrasts with their persecution of the Falun Gong ${ }^{30}$ and house churches. ${ }^{31}$ But an evaluation of the impact of Taiwan's soft power does not simply lie in a crude comparison between China's ban on unrecognized religious associations on the one hand and its recognition of other religious associations on the other hand. It goes further. In Taiwan, politicians of all stripes and persuasions have shown their support for Cheng Yen and the philanthropic activities of her organization. ${ }^{32}$ In doing so, they suggest to Chinese authorities that supporting Ciji could enhance the legitimacy of any regime - be it the Kuomintang or Democratic Progressive Party in Taiwan or CCP in China. We explore the hypothesis that welcoming Ciji in China can also serve to enhance the standing of local leaders in the eyes of central authorities and boost their claim that they work to "win the hearts and minds of Taiwanese "compatriots" ${ }^{33}$ in favour of reunification. Ultimately, gaining the support of local governments for Ciji's activities in China could serve the interests of Taiwan. By encouraging a constituency in China which sees the advantage of peaceful interaction - not confrontation - Taiwan may have more to gain. 
Ciji's presence in China, however, also projects Taiwan's soft power because it showcases the benefits of a relaxed attitude towards religion and a recognition of the services religious organizations provide. Such an approach allows the state to call upon religious organizations to use their human and material resources to assist public authorities in the provision of social services. ${ }^{34}$ Although Ciji cannot substitute the state, successive governments in Taiwan have appreciated the fact that it has helped them fill important gaps in the delivery of social services in disaster relief operations in Taiwan and abroad, in the provision of health care to the poor, and the performance of costly surgical procedures such as bone marrow transplants. ${ }^{35}$ Sobered by Western European models of the welfare state besieged by fiscal woes, the Taiwanese private sector is likely to push for limits to the expansion of the welfare state in Taiwan, despite dramatic ageing of the population. ${ }^{36}$ With a fiscal base too narrow to finance a more generous welfare state because of its relatively low taxation rate, the state bureaucracy may be unlikely to be able to pay for an expansion of the welfare state and may prefer relying on non-governmental forms of support from non-state actors. ${ }^{37}$ China, which also faces rapid ageing of its population, is confronted by an even graver predicament. The fragmented nature of its welfare regime excludes a large proportion of its population. ${ }^{38}$ Tsai's study on the role of communal religions in some counties shows that religious actors at the level of village communities can sometimes assist the state. ${ }^{39}$ The next section presents an even more remarkable example of a religious actor providing social services. Ciji is an outsider with a visible presence in China in spite of unfavourable political relations between Taiwan and China.

\section{Ciji in China and the evolution of cross-Strait relations}

This article is based on research undertaken in the last 10 years in Taiwan and five provinces in China. ${ }^{40}$ The research includes meetings with Cheng Yen, the founder of Ciji; ${ }^{41}$ interviews with high-ranking members of the management team in Ciji's headquarters in Hualien and in Taipei; and interviews with staff, commissioners, and ordinary members in Ciji's branches in Taiwan ${ }^{42}$ Canada,${ }^{43}$ and China. ${ }^{44} \mathrm{I}$ am grateful to Ciji's personnel in Taipei and the new information office located in Guandu, New Taipei, who have generously granted me access to their database, which includes meticulously detailed information about their visits to China. ${ }^{45}$ Before, during, and after their visits to China, volunteers wrote testimonies about their experiences, impressions, and thoughts, many of which have found their way into publications. ${ }^{46}$ The original material was collected in Taipei, and it contained much useful information about fact-finding investigations (發放) and relief operations (救濟) which Ciji had undertaken up until 2001. I have also relied on books summarizing these operations, which were published in abridged versions in English in $2000^{47}$ and in more detailed versions concerning specific missions in Chinese. ${ }^{48}$ After Ciji's documentation centre relocated to Guandu, I had to depend on summaries of Ciji's activities in China which have been published in its annual reports since $2005 .{ }^{49} \mathrm{I}$ have also referred to Ciji's website in China for details of these activities at the provincial level after 2008..$^{50}$ There is a short gap between 2001 and 2004, but enough information of Ciji's presence in China can be gleaned from later reports.

Ciji's activities in China and its contribution towards the improvement of cross-Strait relations are part of a broader trend in which religious organizations have helped to 
enhance Taiwan's public diplomacy. For example, in his comparison between Chinese and Taiwanese overseas humanitarian assistance programmes in developing countries, Tubilewicz noted that an important difference between the two was the willingness of Taiwanese to engage with Buddhist and Christian religious institutions from Taiwan in post-disaster recovery, something which China does not do when it mobilizes Chinese non-state actors in its operations overseas. ${ }^{51}$ We can thus look at the expansion of Ciji's activities in China in the context of Taiwan's public diplomacy vis-a-vis cross-Strait relations: Taiwan must rely on non-state actors and person-to-person interactions to a greater extent than other countries because of its precarious status in the international community. ${ }^{52}$ Chinese authorities are certainly aware of the importance of religion in the definition of a distinctive Taiwanese identity, ${ }^{53}$ and may see little need to cultivate good relations with the Presbyterian Church because of the latter's strong stance on the Taiwanese right to self-determination. However, they are also aware of the huge popularity of organizations such as Ciji that do not take an overt position on that issue and therefore can facilitate cross-Strait interactions at a non-governmental level.

Ciji had already established a solid track record in Taiwan for 25 years when it considered doing international relief work. It has founded and successfully managed a hospital in Hualien, a previously impoverished region in eastern Taiwan. The activities of Ciji in Taiwan can be divided into eight different categories: charity, medical help, education, cultural services, bone marrow transplants, international relief, environmental protection, and community work. ${ }^{54} \mathrm{Ciji}$ has always maintained cordial relations with the Taiwanese government and many see in its moral stature and authority the source of its influence and ability to shape the government's social policies. ${ }^{55}$ Through its activities in Taiwan and overseas, Ciji has gained considerable experience that serves it well in China. The religious values that have inspired its volunteers in Taiwan and abroad have sustained the organization, but this dimension of its work had to be downplayed in China. For obvious political reasons, the activities in mainland China do not fall under the category of international relief, as people living in China are considered 'compatriots' in the literature that Ciji distributes at its cultural centre. Until 2008, when Ciji registered as an NGO in China, its activities covered the first three of the categories listed. After that, it also engaged in cultural activities and in environmental awareness projects. ${ }^{56}$

The activities of Ciji's volunteers in China are guided by the same five principles that they adhere to in Taiwan and elsewhere. The first of these principles, directness, means that aid must reach victims of natural disasters directly, without the intervention of a third party. The application of this principle cannot, obviously, mean bypassing the authorities in China: Ciji volunteers fulfil this part of their pledge by ensuring they are present with local Party and government officials in public meetings in which hundreds of people from the affected communities are assembled to receive relief. The second principle, priority, emphasizes the necessity of offering relief to the areas which are hit the hardest. ${ }^{57}$ The other three principles advocated by Ciji volunteers - respect for local lifestyle, customs, cultures, and traditions; timeliness of the provision of relief; and parsimonious use of resources - do not at all present a particular problem for the Chinese authorities. During the distribution of relief, Ciji volunteers must respect another principle that China insists on. It concerns the Three No's (三個不為): no politics, no religion, and no propaganda (不談政治、不刻意傳教、不搞宣傳) ${ }^{58}$ 
Negotiations for the admission of Ciji's volunteers into China took place at a very critical time. Following the military crackdown on Tiananmen against the pro-democracy movement, China was engulfed in a wave of international indignation. The government sought to surmount this hurdle by promoting person-to-person, non-governmental, and religious diplomacy ${ }^{59}$ During that time, some officials hoped that international agencies established in Hong Kong and Macao, such as the Salvation Army, Oxfam, and the Jian Hua Foundation, which have provided relief to China since 1987, would return and resume their activities. ${ }^{60}$ Their views, however, were opposed by cadres in public security, united front work, and religious affairs, who were concerned about religion being used for subversive purposes, which they believed was responsible for regime change in Poland. Cadres in the ministries of commerce and civil affairs, however, were concerned about continuation of the reform policy and China's international standing, and they finally prevailed thanks to Deng Xiaoping's decisions. Among this group of cadres, Yan Mingfu, disgraced earlier because of his effort to negotiate between the Party and students at Tiananmen Square when he headed the Party United Front Work Department, was tasked in 1991, as the Vice-Minister for Civil Affairs, to talk with representatives from Ciji. ${ }^{61}$ The fact that $\mathrm{Ciji}$ was not registered as a religious association in Taiwan probably facilitated the negotiations as the Bureau for Religious Affairs did not have to get involved. ${ }^{62}$

Ciji thus launched its first relief missions in 1991, following an invitation to Beijing by Vice-Minister Yan ${ }^{63}$ to Ciji's Vice-Director Wang Tuan-cheng ${ }^{64}$ to discuss the extent of the damage caused by floods in Anhui and to ascertain the nature of the help Wang's organization could provide. ${ }^{65}$ During his visit in Beijing, Wang and his delegation also met Tang Shubei, the then newly appointed Deputy Director of the CCP Central Committee Office for Taiwan Affairs ${ }^{66}$ These meetings took place while Chinese and Taiwanese authorities were indirectly conducting negotiations to improve relations across the Strait, via the Association for Relations Across the Taiwan Strait (ARATS, 海峡两岸・系协会) and the Strait Exchange Foundation (SEF, 海峽交流基金會). Following a report by Wang and the small team of volunteers that had accompanied him to Anhui to assess the situation, Ciji's founder Cheng Yen decided to offer relief in six counties in Anhui in the areas designated by local authorities. ${ }^{67}$ Another relief operation was also launched in Jiangsu following a request for help from the Xinghua County Association in Taipei.

In 1992, following this tacit endorsement of its activities, Ciji increased its presence in China. Besides helping with recovery and reconstruction in communities in Anhui and Jiangsu, Ciji's volunteers also went to new areas. They distributed relief supplies to flood victims in six counties in Hunan and two in Henan. The operation in Hunan was unprecedented in scale and in the support received from local authorities: Ciji volunteers provided five months' worth of rice rations, 166,000 sets of winter clothing, and 46,000 comforters to 83,000 victims. For that relief effort, 1,500 workers in garment factories in Quanjiao and Changsha were involved. Quanjiao authorities requested and obtained the People's Liberation Army's help to deliver clothing from Anhui to Hunan. This interprovincial coordination showed support from Beijing authorities. Ciji did more than just provide relief. In Jiangsu it built nine schools; in Anhui 14 communities, nursing homes for the elderly, and three schools; in Henan 1,954 houses and two clinics; and in Hunan 
it helped build two clinics and a village. In 1993, it provided disaster relief in Hunan and offered medical services in cooperation with local medical institutes in Jiangsu. In 1994, it provided relief in Hunan, Guangxi, and Guangdong. In 1995, Ciji provided relief in five provinces, offered scholarships in two others, and added Jiangxi and Liaoning to the provinces whose communities it assisted. In addition, its Canadian branch donated enough money to finance 13 nursing homes in nine provinces.

In 1996, relations across the Strait changed dramatically as Jiang Zemin overtly tried to influence the Taiwanese electorate by ordering missile tests. However, this did not prevent Ciji from maintaining a presence in China. Quite the opposite: three new provinces welcomed volunteers from Taiwanese organizations, and by then Ciji had been active in 17 counties across China. Ciji's volunteers delivered disaster relief in Qinghai, Yunnan, and Fujian; built Ciji villages in Zhangjiakou (Hebei) and Jiangxi; and Ciji schools in Liaoning and Jiangxi. Clearly, local governments in all these areas did not see any point in punishing Ciji for the alleged affront following the controversial visit of President Lee Teng-hui to the United States. In 1996, the number of people who benefited from Ciji's activities increased by 40 per cent. In Taiwan, however, the relief provided by Ciji to mainland Chinese upset many voters, who interpreted this action as supporting a regime whom many saw as bent on destroying their society. ${ }^{68}$ In 1997 , despite tensions across the strait, Ciji provided relief to the provinces of Zhejiang and Fujian following Typhoon Herb and opened a Ciji children's welfare institute in Wuhan. ${ }^{69}$

By 1998, cross-Strait relations experienced further deterioration, as even semi-official negotiations between ARATS and SEF broke down. Yet, reports from Ciji suggest that this freeze in relations did not prevent it from continuing its work. Alongside its relief activities in Anhui, Fujian, Guizhou, Hunan, and Jiangxi, it opened two Ciji schools in Anhui and constructed a new one in Guizhou, offered over 3,000 scholarships, performed bone marrow transplants in Hainan and Zhejiang, and organized a three-month global fundraising drive for flood victims in China. In 1999, despite increasing tensions in cross-Strait relations, Ciji provided disaster relief in three provinces, offered scholarships to over 3,700 students, and opened two schools. Its doctors performed 16 bone marrow transplants throughout the country, and Ciji built over 500 water reservoirs in Gansu.

By the summer of 2000, tensions heightened within China and across the Taiwan Strait. Jiang Zemin ordered a clampdown on the Falun Gong and other 'heretical sects', which suggested a hardening of the central government's attitude towards religion. In Taiwan, the Democratic Progressive Party (DPP) candidate Chen Shui-bian, known for his pro-independence views, won the presidential election. In 2001, the DPP's position was reinforced in the elections of the Legislative Yuan, when the party won more than one-third of the seats. But the release of documents on religious affairs and a policy of encouragement towards Buddhist institutions suggested at least two reasons for supporting the presence of Ciji in China. Firstly, as a well-established Buddhist charity in Taiwan, Ciji could be used as a model of institutionalization for the development of a Buddhist charity in China. Moreover, its professed attitude of providing relief to compatriots made it a possible ally for the Party's united front work in favour of reunification. This impression was reinforced by the attitude of other Buddhists in Taiwan, who had publicly opposed the election of Chen. ${ }^{70}$ 
The activities of $\mathrm{Ciji}$ in China therefore continued unabated during the first Chen administration. In fact, they even increased in scope, including provision of relief in territories that are considered sensitive by Chinese central authorities. Hence, Ciji provided help to children in Tibet in 2002 and disaster relief in Xinjiang in 2003. ${ }^{71}$ In December 2002, directors of Ciji high schools from five provinces met at Ciji's headquarters in Hualien and expressed their gratitude. There were even signs that Ciji was trying to establish a permanent base in China regardless of the difficulties in relations between Taipei and Beijing. Volunteers in Beijing made preparations for Ciji's relief operations in Xinjiang. ${ }^{72}$ The re-election of Chen in 2004, in short, did not dissuade Chinese authorities from the utility of Ciji's volunteers in China: data from 2005 until 2008 show a continuation and a diversification of its activities. ${ }^{73}$ The achievements of Ciji in China during the second mandate of Chen Shui-bian confirm that local authorities chose to ignore the political implication of the DPP in power.

Sixteen years after its arrival in China, Ciji has managed to provide relief in almost all provinces, autonomous regions, and municipalities except Shanxi, Jilin, and Chongqing. Its report for the spring of 2006 showed that by that time, it had performed a total of 397 bone marrow operations in 12 provinces and municipalities, built 33 project hope schools in eight provinces and in Xinjiang, 3,800 houses in eight provinces, 13 day-care centres in nine provinces, two hospitals in Fujian and Jiangsu, 10 nursing homes for the elderly in two provinces, and 3,951 water cellars in Gansu. ${ }^{74}$ In addition, Ciji has launched programmes to grow low-fluoride brick tea in Tibet and wealth barley in Qinghai. Ciji has established a permanent presence in some form in 15 of China's 20 provinces in which it has provided relief, ${ }^{75}$ and in four of China's autonomous regions ${ }^{76}$ During the last three years of the Chen administration in Taiwan, Ciji did not stop its operations in China. From 2005 to 2008, it built 597 new houses and 16 new schools. It also performed 351 bone marrow transplants, which represents almost a doubling of numbers as compared to the period before $2005 .{ }^{77}$ In 2007 , for the first time, it also performed cataract operations on 1,434 children in its Guangming programme. ${ }^{78}$

From the preceding, it is clear that the help Ciji provides is not uniform and that it varies from one province to another, depending on the respective needs of various localities. There are no obvious reasons as to why some provinces welcome Ciji and not others. For instance, Ciji operates senior citizens homes in only two provinces, Anhui and Jiangsu, which have contrasting social economic conditions; Ciji's physicians have operated on people suffering from cataract in only two provinces, Jiangsu and Fujian, even though the problem may be more pressing elsewhere. Some projects are specific to a province or city, and not carried out in other places; for example, Ciji has provided water cellars only in the province of Gansu even though other provinces face serious problems of aridity. Ciji financially supports a children's welfare home in Wuhan, but there have been no other projects of this kind until 2008. The data available so far suggest that some projects were made possible because of long-established connections between individual Ciji volunteers and their relatives, as the case of Xinghua County in Jiangsu demonstrates. But as a rule, there is no broad development plan, only a preparedness to respond to disaster wherever it strikes. This readiness explains in good part why, despite $\rightarrow$ legal status in China, Ciji has affirmed its presence in the country and has become hiliar name among Buddhists, scholars working on religion and disaster relief, and those in the general public interested in developments in Taiwanese civil society. 
In 2008 two dramatic events that occurred independently profoundly affected the context of Ciji's operations in China and, arguably, offered Ciji an opportunity to put down its roots there. First, as suggested earlier, the election of Ma Ying-jeou has changed the tone in relations between China and Taiwan for the better. Although China has always extended a welcome to Taiwanese businesspeople (taishang 台商) in the hope that the latter would dampen pro-independence sentiments, Ciji had never been sure of China's open arms. The election of a politician seemingly resolutely opposed to Taiwanese independence appeared to have vindicated Hu Jintao's more cautious policy, in contrast to the approach adopted by Jiang Zemin in 1996. Arguably, Ma Ying-jeou's election as president created goodwill towards Taiwanese in general. Second, the devastating earthquake that struck Sichuan in 2008 generated an outpouring of sympathy worldwide and an unprecedented response from Chinese civil society. The Chinese government, sensing the need to gain all the support possible in the wake of such a disaster, accepted help from Japan and Taiwan. ${ }^{79}$ Help from the latter came from the Taiwan Red Cross Society and two Buddhist associations, including Ciji. ${ }^{80}$ In no time, Ciji's volunteers from Beijing, Guangdong, Fujian, and Shanghai delivered relief to the victims of the earthquake. ${ }^{81}$

Ciji's contribution during the Sichuan earthquake prepared the way for the institutionalization of its activities in China. Ciji was officially registered in 2010. In that year the first local office of an overseas NGO was opened in China, in the city of Suzhou. The opening ceremony was attended by Chen Yunlin, chairman of ARATS, and Qi Xiaofei, deputy director of the State Administration for Religious Affairs (SARA). ${ }^{82}$ The presence of Chen and Qi was significant for a number of reasons. Chen's presence demonstrated the importance of Ciji in nurturing cross-Strait relations, but more significantly, Qi's attendance demonstrated the central government's approval of the activities undertaken by a Buddhist association in the provision of social services. This recognition would go very far. In the same year, the municipal government of Suzhou agreed to give Ciji land on which to build a social services centre. In 2011, the centre was completed and its size was comparable to Ciji's headquarters in Hualien.

Ciji's decision to establish its headquarters in Suzhou was facilitated by the municipal government's gift of land to Ciji. ${ }^{83}$ This action, in turn, needs to be seen in the broader context of Suzhou's relations with Taiwanese business. In a study on the information technology industry in the region, Pereira argues that Chinese authorities encouraged more Taiwanese business enterprises to locate there in order to limit the influence of their Singaporean counterparts who had established the China-Singapore Suzhou Industrial Park. ${ }^{84}$ The strong presence of Taiwanese in the city may explain why municipal authorities tolerated, if not promoted, the presence of an institution such as Ciji that caters to the spiritual needs of Suzhou residents. This connection between Ciji and Taiwanese business is apparent in many aspects, from the supply of equipment made in Taiwan to the presence of Taiwanese volunteers in Suzhou, who are relatives of Taiwanese businesspeople residing in the area. The Suzhou government and higher levels of authority are likely to approve such a connection, as it nurtures a constituency with a vested interest in stable relations across the Taiwan Strait. Ngo's study of the influence of Taiwanese business in cross-Strait negotiations at the beginning of the 2000 s makes the same point. ${ }^{85}$

The future of Ciji's growth in China, however, faces an important hurdle, which may explain in part why Chinese authorities are not perturbed about its expansion. The 
control and administration of many of Ciji's institutions such as schools and clinics are in the hands of local Chinese, and an overwhelming majority of its volunteers are Taiwanese residing in China. Many of the institutions that Ciji helped to build or repair have been financed with funds from Ciji, but the teachers and the medical staff are Chinese. However, it will be difficult for Ciji to avoid surveillance by the authorities. Yet some feel that Ciji is receiving more support than other Buddhist charities do ${ }^{86}$ The fact that until recently Ciji volunteers could not spread their religious teachings openly has also limited their visibility among Chinese. But this may be changing, as the teachings of Cheng Yen have been made available and as the government increasingly encourages the growth of Buddhism to check the growth of Christianity. Cheng Yen and all of Ciji's volunteers interviewed over the years hope that a growing number of people in China will join them. But admission into Ciji requires rigorous training that may last up to two years, and therefore the rise in the number of Chinese members has been very slow.

The evidence presented so far does not suggest any link between crises in the Taiwan Strait and the acceptance of Ciji in China. Clearly local governments that welcomed Ciji's volunteers in their midst believed that the natural disasters and social problems which affected them mattered more than the progress in cross-Strait relations. Putting the extent of the services which Ciji offers into perspective, Ciji's contribution appears modest. In 2010, there were over 280,000 elementary schools in China. ${ }^{87}$ Ciji has set up 54 schools. The Narada Foundation, one of China's largest corporate charities, only started operations in 2007, with the aim of helping 100 schools, ${ }^{88}$ which makes Ciji's contribution of 54 schools all the more remarkable. Ciji has been remarkably successful in another respect. It has inspired Chinese Buddhist associations, monks, and laypeople to establish their own charities. At the time of writing, Buddhist philanthropic associations in Shanghai, Shijiazhuang, Tianjin, and Xiamen, some of which are 20 years old, are thriving. In 2012, a delegation from the Donglin Buddhist Charity, a major Chinese association, visited Ciji's cultural centre in Suzhou to exchange views. ${ }^{89}$

\section{The Chinese state's approach to religious social services}

The presence of Ciji in China has strengthened bonds across the Taiwan Strait. Ciji's philanthropic activities and services and its relations with the state reveal a major contrast between Chinese and Taiwanese state approaches to organized religion. Ciji's increasing presence in China since 1991 may however indicate a convergence between the two states' approaches in recent years. Both the Kuomintang in Taiwan and the CCP claim affiliation with the approach to religion adopted by modernizers since the late Qing, who sought to reform religion in China, but after 1949 the views and policies of the Kuomintang and CCP diverged radically in the three decades that followed. ${ }^{90}$ Are there signs that these views could be converging now? A growing amount of research on the relationship between the Chinese government and organized religion suggests that we should not limit our sights to an examination of state policy towards religion and assume that religion is subordinated to secular authorities. Studies show that when the state tries to co-opt religious institutions to serve its own policies, religious actors seize the opportunity to empower themselves. ${ }^{91}$ This is especially true when the state is divided by rivalries and weakened by foreign interference. However, with respect to Ciji, it is too 
vulnerable to manipulate the very process that has given it access into China, and therefore, the paradigm of state control remains relevant.

Late-Qing modernizers and their successors believed that the material resources of religion should serve society. With this goal in mind, they launched a movement to convert temples into schools at the end of the Qing and at the beginning of the Republican period. $^{92}$ The movement abated, but it left an institutional legacy in many of the regulations in Taiwan today, one of which requires temples to allocate a proportion of their wealth to public services. ${ }^{93}$ This policy was welcomed by Christian churches and the Catholic Church, but Buddhist, Taoist, and communal religious institutions were more ambivalent because of disputes with the government over property and they were reluctant to give a proportion of their resources to charities. This was a major source of disagreement between the state and religious institutions until the 1990s. ${ }^{94}$

Such conflicts, however, paled in comparison with what co-religionists faced on the other side of the Taiwan Strait after 1949. From then until the onset of the Great Leap Forward, the CCP sought to impose tight control over religion, on the premise that the latter would disappear, and therefore religious leaders had to cooperate with the state to hasten that outcome. The last two decades of the Maoist regime were characterized by oppression to the extent that religious associations ceased to exist altogether. Buddhist monks, for example, had to recant, and monasteries were closed or transformed into buildings for other purposes. People's communes became the main providers of social services in the countryside, and state-owned enterprises performed the same functions in urban areas. Unsettling political conditions, widespread poverty, and the attack on traditions prevented religious associations from playing any meaningful social role. ${ }^{95}$

In the meantime, the cultural renaissance movement launched by Chiang Kai-shek in 1966 aimed at producing the opposite. Although none of the 10 points promoted by the movement aimed specifically at reviving religion per se, the movement provided a germane context, with an emphasis on Confucian filial piety, the encouragement of good morals, the promotion of the 'eight virtues', the preservation of cultural heritage, and perhaps, most significantly, the revision of the tax code to encourage wealthy businesses to invest in government-approved cultural and educational institutions. ${ }^{96}$ It is in that environment that Ciji was created in 1966, and in 1972, it established its first free clinic for the poor. Under the tenure of Chiang Kai-shek's son Chiang Ching-kuo (1978-88), the cooperation between the state and Taiwan's religious associations increased significantly, with the ROC president helping Ciji secure land on which to establish its hospital in Hualien, which opened in $1986 .^{97}$

After 1978, the CCP also underwent dramatic changes in the regulation of religious affairs. Deng Xiaoping put an end to persecutions and encouraged the rebuilding of institutions. However, his policy did not go as far as allowing religious institutions to develop activities besides the performance of religious rituals. The understanding among CCP intellectuals was still that religion was bound to wither away and that the state merely had to ensure that this process would not be imposed through force. ${ }^{98}$ Therefore, local governments did not expect religious institutions to provide social services, even though, under Deng's guidance, the dismantling of people's communes was not followed by state provision of social services in the countryside. The shortcomings of China's social policies were not apparent in light of the remarkable increase in peasants' wealth following 
the implementation of the family responsibility system and the overall success of the Chinese economy during the first stage of the reform. ${ }^{99}$

During the tenure of President Lee and his successors Chen and Ma, Taiwan's economic growth did not lead to a welfare regime based on state provision of social services. Relative to Organisation for Economic Cooperation and Development (OECD) states at a comparable stage of development, Taiwan's social policies are far less generous. ${ }^{100} \mathrm{It}$ is this context that underlines the relevance of Taiwan's liberal approach to the regulation of religious affairs. Expanding space for religious actors during the 1990s signalled the legal recognition of an increasing number of religions. This process of legalization aligned Taiwan with other liberal democracies. ${ }^{101}$ Such openness was an encouragement to religious organizations to set up charities, engage in philanthropy, and provide social services in education, health care, counselling, and environmental protection.

In this regard China differs significantly from Taiwan and European countries. During Jiang Zemin's tenure, rapid economic growth could not offset negative outcomes such as growing social inequalities and inadequacies in social services. CCP policies on religious affairs have changed, in recognition of the fact that religion is likely to matter in Chinese society for a long time. However, Jiang also ordered the persecution of the Falun Gong, a religious movement that had appeared to challenge the government's policy on health care. Jiang did not follow Taiwan's policy, and he enforced regulations that forbade religions to perform activities besides dharma lectures, prayers, mass, and other approved forms of worship. ${ }^{102}$ Yet, as the presence of Ciji in China since 1991, and the activities of some local associations since then suggest, local governments have been authorized to try out policies that depart from the official norm.

The growth of Buddhist charities, debates among academics and SARA's officials about religion, and public interest indicate a shift away from strict adherence to Deng's and Jiang's policies under Hu Jintao's administration. ${ }^{103}$ Although many Party leaders still oppose the recognition of Confucianism or communal religions as a sixth Chinese religion, signs of acceptance of the provision of social services by religious actors abound. The encouragement shown by Suzhou's municipal government towards the establishment of Ciji's centre in the city confirms state approval. Authorities now appear to look at religious actors as useful complements to state provision rather than competitors in their attempts to develop a more generous regime of pension, universal access to health care and to education, as well as disaster relief and poverty alleviation. In that sense, it is not too far-fetched to argue that the Chinese government recognizes the utility of Taiwan's approach in which religious actors assist the state in the provision of social services.

The transformation of Ciji from a small monastic community into the largest philanthropic association in Taiwan was made possible by the increasingly liberal approach in the regulation of religious affairs. This served the interests of different branches of the Taiwanese government and those of the Kuomintang very well. On the one hand, local governments could rely on a philanthropic association to provide health care. The Ministry of Foreign Affairs and the Government Information Office have been able to present Ciji to the international community as an example of Taiwan's tolerance towards religion. The achievements of Ciji in disaster relief are promoted by the Ministry of the Interior as an example of responsiveness on the part of civil society. Finally, the supportive attitude of the Kuomintang towards Ciji from Chiang Ching-kuo onwards has ensured 
that $\mathrm{Ciji}$ does not oppose the party and its candidates. In that respect, one can understand Ciji's appeal to Chinese leaders.

More subtly, Ciji's presence around the world, via its branches and in its relief operations, promotes a positive image of Taiwan as a caring society of selfless individuals. Because Ciji appears to keep governments at arms-length, it convincingly promotes the idea that religion is not under the control of the state and that freedom of religion, which has allowed the growth of charities into philanthropic organizations providing health care and education, serves the public interest. There is little doubt that in past years the contrast between this approach to religion and the public good has put Taiwan in a far better light than China with its regulatory regime of repression against house churches and Falun Gong. That local governments in China allow religious organizations to offer social services suggests a change in the reception of Chinese authorities towards religious organizations. The exchange of views between Chinese Buddhists and Ciji's volunteers and the visits of local Chinese officials to Ciji's global headquarters in Hualien strongly suggest that Ciji's activities in Taiwan and China have contributed to a shift in attitude.

But we should not exaggerate the impact of Ciji on official policy: the state has its own reasons for its favourable reception towards Buddhists and their philanthropic activities in China, regardless of whether they come from Taiwan or the mainland. ${ }^{104}$ Research has provided mounting evidence that government officials have tried to co-opt unregistered China-based Christian groups since 2000, but this accommodating approach has undermined the state's control of religious affairs, as shown by the proliferation of unregistered churches in rural and urban areas, which have advanced their own evangelistic and social agendas through their connections with provincial and district authorities. ${ }^{105}$ Seen in this light, we can interpret the state's deliberate promotion of Buddhist - and arguably Taoist - organizations as an attempt to pre-empt the rise of Christianity. In sum, Ciji may have helped to loosen the state's regulation of religious life and the scope of religious activities, but relations between the government and many religious actors remain contentious. ${ }^{106}$

\section{Conclusion}

We began by acknowledging that Ciji represents one of the most important assets for the deployment of Taiwan's soft power in relation to China whose military and economy have grown in strength. Ciji's growth has been made possible in a society that not only supports freedom of religious beliefs and practice but also encourages the involvement of religious organizations in the provision of social services. The gradual expansion of Ciji's presence in China contrasts with the vicissitudes of bilateral relations between Taipei and Beijing, interspersed by episodes of tension and overtures. This shows that while local governments in China found that there was a lot to learn from Ciji's strengths, the Chinese central government also saw in the apolitical nature of Ciji's activities an appealing and reassuring aspect. In the end the opportunity to learn from Ciji appeared to many Chinese officials more valuable than the points they could have scored if they had decided to expel Ciji from China to punish Taiwan for the actions and statements of its politicians. Many Buddhist associations in China have developed fruitful exchanges 
with Ciji and have adopted its approach towards philanthropy, to the benefit of local welfare. It is too early to tell whether these changes are irreversible, but Ciji's activities in Taiwan have convinced many local governments in China that they should adopt the practice of the Taiwanese government towards religious associations and encourage their involvement in social services, an approach that authorities in Taiwan have nurtured.

By adopting a utilitarian approach to religious intervention in the delivery of social services in Taiwan, Kuomintang leaders from Lee Teng-hui to Ma Ying-jeou have followed in the footsteps of late Qing and Republican modernizers who initiated the movement to 'turn temples into schools'. Kuomintang leaders have thereby reinforced the legitimacy of the ROC as an alternative Chinese modernity that preserves both Chinese culture and freedom of conscience. This claim, however, is mainly directed at a Taiwanese audience, and those among them in the pan-Green camp who do not subscribe to the discourse on Taiwan's Chinese identity have shrugged it off. Taiwan's influence on China, moreover, is limited. It is quite plausible that Jiang Zemin and Hu Jintao have gradually encouraged religious organizations to provide social services after the example set by Ciji in Taiwan and the controlled experiment of Ciji's limited presence in China which convinced them that $\mathrm{Ciji}$ does not present political risks and could even enhance regime legitimacy. The $\mathrm{CCP}$ now seems inclined to embrace the Kuomintang's idea that religion can serve the modern state, but it has not yet adopted Taiwan's more laissez-faire attitude in the regulation of religious affairs. As such, Taiwan's soft power has yet to prevail decisively on China.

\section{Funding}

This research received no specific grant from any funding agency in the public, commercial, or not-for-profit sectors.

\section{Notes}

I would like to thank the following institutions and individuals for their support: Hong Kong University's Institute for Humanities and Social Sciences for letting me use their facilities and providing a very congenial environment; the Social Science and Humanities Research Council of Canada for its financial assistance; two anonymous reviewers for their very helpful comments; and numerous interviewees within Ciji who were generous with their time. All remaining errors are mine alone.

1. It is known in Taiwan and abroad in English simply as Tzu Chi.

2. Benjamin Kang Lim, Taiwan Buddhist charity Tzu Chi sets up shop in atheist China, Reuters, 20 August 2010, http://blogs.reuters.com/faithworld/2010/08/20/taiwan-buddhistcharity-tzu-chi-sets-up-shop-in-atheist-china, accessed 4 October 2012.

3. See Yao Yu-shuang, Taiwan's Tzu Chi as Engaged Buddhism: Origins, Organization, Appeal and Social Impact, Leiden: Global Oriental/Brill, 2012; Mark O’Neill, Tzu Chi: Serving with Compassion, Singapore: John Wiley \& Sons, 2010; Julia Huang, Charisma and Compassion: Cheng Yen and the Buddhist Tzu Chi Movement, Cambridge, MA: Harvard University Press, 2009; and Ding Renjie, Shehui mailuozhong de zhuren xingwei: Taiwan fojiao Ciji gongdehui ge'an yanjiu (Helping behaviour in social context: The case of the Taiwanese Buddhist Ciji Merit Society), Taipei: Lianjing chubanshe, 1999. 
4. On law and religion in China, see Beatrice Leung, China's religious freedom policy: The art of managing religious activity, The China Quarterly, no. 184, 2005: 894-913; Pitman Potter, Belief in control: Regulation of religion in China, The China Quarterly, no. 174, 2003: 317-37.

5. Ted Galen Carpenter, Ma Ying-jeou's victory provides respite - not resolution in cross-Strait tensions, China-US Focus, 25 January 2012, http:/www.chinausfocus.com/peace-security/ ma-ying-jeou\%E2\%80\%99s-victory-provides-respite\%E2\%80\%94not-resolution-in-crossstrait-tensions/, accessed 18 September 2012; Denny Roy, Taiwan: Crisis deferred, but maybe not for long, Asia Pacific Bulletin, no. 145, 19 January 2012, 1-2; and Alan D. Romberg, After the Taiwan elections: Planning for the future, China Leadership Monitor, no. 37, Spring 2012: 1-25.

6. Although the diplomatic truce between China and Taiwan has been uneasy since the election of Ma, Taiwan still seeks recognition of its right to international participation. See T. Y. Wang, Wei-chin Lee, and Ching-hsin Yu, Taiwan's expansion of international space: Opportunities and challenges, Journal of Contemporary China 20(69), 2011: 249-67.

7. Anne Welle-Strand, Chen Pei-Fen, and Graeme Ball, The Taiwanese economic 'miracle': Continuing?, East Asia 28(4), 2011: 329-50.

8. S. Philip Hsu, Yu-shan Wu, and Suisheng Zhao (eds), In Search of China's Development Model: Beyond the Beijing Consensus, New York: Routledge, 2011; Justin Yifu Lin, Fang Cai, and Zhou Li, The China Miracle: Development Strategy and Economic Reform, Hong Kong: Chinese University Press, 2003.

9. David A. Shlapak, David T. Orletsky, Toy I. Reid, Murray Scot Tanner, and Barry Wilson, A Question of Balance: Political Context and Military Aspects of the China-Taiwan Dispute, Santa Monica, CA: RAND Corporation, 2009.

10. Romberg, After the Taiwan elections, 10-11.

11. Hence, during Taiwan's presidential elections or during the trial of Chen Shui-bian for corruption, many netizens in China have wondered out loud why people in the PRC could not enjoy the same rights and why CCP politicians guilty of corruption could not face justice. See Xiao Qiang, Taiwan's election on Sina Weibo, China Digital Times, 13 January 2012, http:// chinadigitaltimes.net/2012/01/taiwans-election-on-sina-weibo/, accessed 18 September 2012.

12. Joseph Nye, Bound to Lead: The Changing Nature of American Power, New York: Basic Books, 1990.

13. Joseph Nye, Soft Power: The Means to Success in World Politics, New York: Public Affairs, 2004, 11; Hongying Wang and Yeh-chung Lu, The conception of soft power and its policy implications: A comparative study of China and Taiwan, Journal of Contemporary China 17(56), 2008: 425.

14. On this specific issue, see Jacques Deslile, Soft power in a hard place: China, Taiwan, cross-Strait relations and U.S. policy, Orbis 54(4) Fall 2010: 494-524; Wang and Lu, The conception of soft power.

15. Deslile, Soft power in a hard place, 493.

16. Ibid., 511.

17. Wang and $\mathrm{Lu}$, The conception of soft power, 431, give the example of Lin Bih-jaw, former National Security Councillor under presidents Lee and Chen and Deputy SecretaryGeneral of the Presidential Office; Lin Bih-jaw, Yi ruanxing liliang, kaichuang liang'an xinju (Wielding soft power to create a new situation in cross-Strait relations), China Times (Taipei), 12 May 2004, A15.

18. Arthur S. Ding and Paul A. Huang, Taiwan's paradoxical perceptions of the Chinese military: More capable but less threatening?, China Perspective, no. 4, 2011: 43-51.

19. Wang and Lu, The conception of soft power, 431-32; Lin Bi-jaw, Yi ruanxing liliang. 
20. Ibid., 426-7.

21. Ibid., 427.

22. Ibid., 428. Former US Special Representative for Nuclear Non-proliferation Christopher Ford has even pointed to the emergence of a neo-Confucian discourse in the Chinese media that feeds on the alleged failures of Western capitalism. See Christopher A. Ford, "Occupy Wall Street" and Communist China's Emerging "Neo-Kong” Discourse of Antidemocratic Legitimacy, Security and Foreign Affairs/Briefing Paper, Washington, DC: Hudson Institute, 2012.

23. Wang and $\mathrm{Lu}$, The conception of soft power, 432.

24. For the role of Taiwanese business in that particular dimension of cross-Strait relations, see Chun-yi Lee, Taiwanese Business or Chinese Security Asset: A Changing Pattern of Interaction between Taiwanese Businesses and Chinese Governments, London: Routledge, 2011.

25. Shawn Shieh and Guosheng Deng, An emerging civil society: The impact of the 2008 Sichuan earthquake on grass-roots associations in China, The China Journal, no. 65, 2011: 181-94; Jonathan Schwartz and Shawn Shieh (eds), State and Society Responses to Social Welfare Needs in China: Serving the People, London: Routledge, 2009.

26. Gladys Pak Lei Chong, Volunteers as the 'new' model citizens: Governing citizens through soft power, China Information 25(1), 2011: 35-59; Timothy Hildebrandt, The political economy of social organization registration in China, The China Quarterly, no. 208, 2011: 970-89; Patricia M. Thornton, Crisis and governance: SARS and the resilience of the Chinese body politic, The China Journal, no. 61, 2009: 23-48; and Peter Ho, Embedded activism and political change in a semiauthoritarian context, China Information 21(2), 2007: 187-209.

27. Wang and $\mathrm{Lu}$, The conception of soft power, 433-4.

28. This point was stressed by a high-ranking officer in Ciji.

29. Ciji's volunteers whom I met in China have always insisted that their organization is not a religious one.

30. James T. Richardson and Bryan Edelman, State-fostered violence against the Falun Gong in China, in James R. Lewis (ed.) Violence and New Religious Movements, New York: Oxford University Press, 2012, 379-96; James W. Tong, Revenge of the Forbidden City: The Suppression of the Falun Gong in China, 1999-2005, New York: Oxford University Press, 2009.

31. David C. Schak, Protestantism in China: A dilemma for the Party-State, Journal of Current Chinese Affairs 40(2), 2011: 71-106.

32. Chiu Yu-Tzu, Chen meets Cheng Yen to promote 'policy of peace', Taipei Times, 4 April 2000, 3; Lauren Chen, Lien, Soong look for help from above, Taipei Times, 28 February 2000, 3; and Lee honors nun Cheng Yen, Taiwan Today, 11 February 1989, http://taiwantoday.tw/ct.asp?xItem=7259\&CtNode=122, accessed 18 September 2012.

33. Chu Shulong and Guo Yuli, Change: Mainland's Taiwan Policy, China Security 4(1), 2008: 131.

34. In the 1990s, the Ministry of the Interior had convened meetings with religious associations to discuss these matters. See Neizhengbu (Ministry of the Interior), Zongjiao lunshu zhuanji. Diyi ji: shehui fuwu pian (Discussions on religion. Vol. 1: Social services), Taipei: Neizhengbu, 1994; and Neizhengbu (Ministry of the Interior), Zongjiao lunshu zhuanji. Di'er ji: shehui jiaohua pian (Discussions on religion. Vol. 2: Social education), Taipei: Neizhengbu, 1995.

35. Ciji divides its activities into four main missions: charity, medicine, education, and culture. It is also active in international relief, bone marrow transplants, environmental protection, and community volunteerism. See http://tw.tzuchi.org/en/, accessed 18 September 2012.

36. Chyong-Fang Ko, Kyeung Mi Oh, and Tetsuo Ogawa, Aging population in East Asia: Impacts on social protection and social policy reforms in Japan, Korea, and Taiwan, in James Lee and Kah-Wah Chan (eds) The Crisis of Welfare in East Asia, Lanham, MD: Lexington Books, 2007, 43-70. 
37. Gyu-Jin Hwang, Explaining welfare state adaptation in East Asia: The cases of Japan, Korea and Taiwan, Asian Journal of Social Science 40(2), 2012: 174-202.

38. Sarah Cook and Wing Lam, China's response to crisis: What role for social policy?, in Kevin Farnsworth and Zoë Irving (eds) Social Policy in Challenging Times: Economic Crisis and Welfare Systems, Bristol: Policy Press, 2012, 139-58; Jane Duckett, The Chinese State's Retreat from Health: Policy and the Politics of Retrenchment, New York: Routledge, 2011; and Ngok King-lun, Social assistance policy and its impact on social development in China: The case of the Minimum Living Standard Scheme (MLSS), China Journal of Social Work 3(1), 2010: 35-52.

39. Lily L. Tsai, Accountability without Democracy: Solidary Groups and Public Goods Provision in Rural China, New York: Cambridge University Press, 2007.

40. Hubei, Hebei, Anhui, Jiangsu, and Fujian.

41. All these meetings were in Hualien in Eastern Taiwan.

42. Hualien, Taipei, Kaohsiung, and Chiayi.

43. Vancouver, Toronto, and Montreal.

44. Xiamen, Shanghai, Suzhou, and Nanjing.

45. There is still a considerable amount of information that is unavailable online, in particular details of Ciji's presence in China in the early years.

46. Ciji yuekan (Ciji monthly) and Jingdian zazhi (Rhythms monthly).

47. See Shih Teh-cheng, Xing-ching Lin, and Ching-kui Hsieh (eds), Great Love across the Taiwan Straits: The Tzu Chi Relief Effort in China, 1991-2000, Taipei: Tzu Chi Cultural Mission Center, 2000. The English version of Ciji's website divulges relatively little about its relief activities in China after 2001. Furthermore, these accounts are 'lost' among the other activities undertaken in other Asian countries. For example, see http://tw.tzuchi.org/ en/index.php?option $=$ com_content\&view $=$ category\&layout=blog\&id=3\&Itemid=204\&lan $\mathrm{g}=$ en\&limitstart=48, accessed 18 September 2012.

48. Wang Tuan-cheng, Ai zai liang'anjian huidang (When love transcends the Taiwan Strait), Taipei: Ciji wenhua zhiyue zhongxin, 1999.

49. Detailed versions of these reports for 2005 to 2011 are available at http://tw.tzuchi.org/ index.php?option $=$ com_content $\&$ view $=$ article $\&$ id $=144 \&$ Itemid $=199 \&$ lang $=\mathrm{zh}, \quad$ accessed 18 September 2012.

50. The main URL for Ciji is http://www.tzuchi.org/. The page links to four global sites in English, traditional and simplified Chinese, and Japanese, and to 21 national sites. For detailed information on Ciji's activities in China, see http://www.tzuchi.org.cn/, accessed 18 September 2012.

51. Czeslaw Tubilewicz, The politics of compassion: Examining a divided China's humanitarian assistance to Haiti, International Relations of the Asia-Pacific 12(3), 2012: 449-81.

52. Paul S. Rockower, Projecting Taiwan: Taiwan's public diplomacy outreach, Issues \& Studies 47(1), 2011: 107-52.

53. Paul R. Katz and Murray A. Rubinstein (eds), Religion and the Formation of Taiwanese Identities, New York: Palgrave Macmillan, 2003.

54. This description is valid for all the sites run by Ciji.

55. See Richard Madsen, Democracy's Dharma: Religious Renaissance and Political Movement in Taiwan, Berkeley, CA: University of California Press, 2007, 19; and Huang, Charisma and Compassion.

56. Ciji has never provided relief in Shanxi, but it undertakes environmental work there. See Ciji, Dalu Ciji: Huabei diqu: Shanxi/Shaanxi (Ciji in mainland China: North China area: Shanxi/Shaanxi, http://www.tzuchi.org.cn/index.php?option=com_content\&view=category \&layout=blog\&id=81\&Itemid=331, accessed 4 October 2012 . 
57. Not all areas affected by various natural disasters since 1991 had received help from Ciji.

58. Ciji, Sichuan kaochatuan di Tai Ciji xing (Sichuan investigation team arrives in Taiwan to visit Ciji), 2010, http://www.tzuchi.org.cn/index.php?option=com_content\&view=articl e\&id=1204:2010-09-22-12-40-36\&catid=56:2009-07-13-09-27-50\&Itemid=162, accessed 4 October 2012.

59. I would like to thank an anonymous reviewer for underlining this important point.

60. Miwa Hirono, Civilizing Missions: International Religious Agencies in China, New York: Palgrave Macmillan, 2008.

61. An anonymous reviewer supplied this information.

62. See André Laliberté, The Politics of Buddhist Organizations in Taiwan, 1989-2003: Safeguarding the Faith, Building a Pure Land, Helping the Poor, London: RoutledgeCurzon, 2004, 86; Madsen, Democracy's Dharma, 39.

63. Yan Mingfu would later become the Chairman of the China Charity Federation.

64. Wang is Cheng Yen's brother.

65. Internal report, Anhui 1991, unpublished document from Ciji's archives in Taipei.

66. Ciji's internal document wrongly identifies him as the Chairman of ARATS.

67. Unless indicated otherwise, the data from the next four paragraphs is from Shih et al. (eds), Great Love across the Taiwan Straits.

68. During that time, the activities of Ciji in China were publicly known, but its volunteers and staff were aware of the sensitive nature of their activities and they were uneasy about publicity. Commissioners and employees I had talked to between 1996 and 2008 were torn between their desire to provide relief in China, in the hope of 'sowing the seed of love' across the Strait, and the need to keep quiet about it.

69. During a visit to Wuhan in 2004, members of the local Charity Federation professed ignorance about the history of the institute and its personnel and thought that it had been built by Germans before 1949. A plaque in front of the institute clarified the apparent contradiction: with the support of local authorities, Ciji contributed funding to repair the building, and as it does with the villages, schools, nursing homes which it helped to build, it hands back management to locals.

70. The belief that Cheng Yen would work actively to oppose independence is however misguided. She has always stated that she does not want to get involved in politics, and she expects the same from Ciji's volunteers and employees.

71. Internal reports, Tibet, 2002, and Xinjiang, 2003, unpublished document from Ciji's archives in Taipei.

72. During an interview in 2011 in Suzhou, however, I learned that Ciji is still struggling to recruit volunteers in China. Many of the volunteers in China turn out to be long-term residents related to Taiwanese businesspeople.

73. Risheng He (ed.), Ciji 2005 nianjian (Ciji almanac 2005), Hualien: Fojiao Ciji cishan shiye jijinhui, 2006; Risheng He (ed.), Ciji 2006 nianjian (Ciji almanac 2006), Hualien: Fojiao Ciji cishan shiye jijinhui, 2007; Risheng He (ed.), Ciji 2007 nianjian (Ciji almanac 2007), Hualien: Caituan faren fojiao Ciji cishan shiye jijinhui, 2008; and Risheng He (ed.), Ciji 2008 nianjian (Ciji almanac 2008), Hualien: Caituan faren fojiao Ciji cishan shiye jijinhui, 2009.

74. Chongqing, Jilin, and Shanxi. He, Ciji 2005 nianjian, 428.

75. The following are provinces in which Ciji has extended relief but which do not accommodate a Ciji office or centre: Hainan, Heilongjiang, Shaanxi, Shandong, and Sichuan.

76. Inner Mongolia was the exception.

77. He, Ciji 2005 nianjian, 428; Ciji 2006 nianjian, 373; Ciji 2007 nianjian, 464; and Ciji 2008 nianjian, 484. 
78. He, Ciji 2007 nianjian, 464.

79. Howard D. French and Edward Wong, In departure, China invites outside help, New York Times, 16 May 2008, http://www.nytimes.com/2008/05/16/world/asia/16china.html?_r=1, accessed 18 September 2012.

80. Benjamin Kang Lim, Atheist China gives nod to Taiwan Buddhist group, Reuters, 11 January 2008, http://www.reuters.com/article/2008/03/11/us-china-taiwan-religion-idUSPEK23024220080311, accessed 18 September 2012.

81. He, Ciji 2008 nianjian, 400-4.

82. Jets lift life-saving aid materials to Sichuan, The China Post, 16 May 2008, http://www. chinapost.com.tw/taiwan/national/national-news/2008/05/16/156647/p1/Jets-lift.htm, accessed 18 September 2012.

83. This was mentioned in an interview in Suzhou in the summer of 2012 with one of its communications officers.

84. Alexius A. Pereira, State Collaboration and Development Strategies in China: The Case of the China-Singapore Suzhou Industrial Park (1992-2002), New York and London: Routledge, 2003.

85. Tak-Wing Ngo, Business encirclement of politics: Government-business relations across the Taiwan Strait, China Information 10(2), 1995: 1-18.

86. This was not a criticism levelled at Ciji, but at the local governments for their lack of support given to local Buddhist associations. Criticism did not come from Buddhist clerics or laypeople but from scholars.

87. Ministry of Education, People's Republic of China, Number of schools, external teaching sites and classes in primary schools, 29 December 2010, http://www.moe.edu.cn/publicfiles/business/htmlfiles/moe/s4972/201012/113452.html, accessed 18 September 2012.

88. Narada Foundation, Compassion empowered, http://narada.nppcn.com/indexSTATICblogname_narada, accessed 4 October 2012.

89. Taiwan Ciji bian huanyu: Donglinshanxinfang Gusu (Taiwan's Ciji welcomes Donglin charity's visit to Suzhou), Donglin cishan (Donglin charity), 16 April 2012, http://www. donglincs.com/colA_detail.php?wzid=4455\&lbid=251, accessed 18 September 2012.

90. For a detailed discussion of these issues, see Vincent Goossaert and David Palmer, The Religious Question in Modern China, Chicago: Chicago University Press, 2011.

91. Peter Carroll, Between Heaven and Modernity: Reconstructing Suzhou, 1895-1937, Stanford, CA: Stanford University Press, 2006; Shuk-Wah Poon, Negotiating Religion in Modern China: State and Common People in Guangzhou, 1900-1937, Hong Kong: The Chinese University Press, 2011; and Rebecca Nedostup, Superstitious Regimes: Religion and the Politics of Chinese Modernity, Cambridge, MA: Harvard University Press, 2011.

92. Vincent Goossaert, 1898: The beginning of the end for Chinese religion?, The Journal of Asian Studies 65(2), 2006: 307-35.

93. He Fengjiao (ed.), Taiwan sheng jingwu dang'an huibian: minsu zongjiao pian (Documentary collection of Taiwan's police administration: Folklore and religion), Xindian: Academia Historica, 1996.

94. Charles Brewer Jones, Buddhism in Taiwan: Religion and the State, 1660-1990, Honolulu: University of Hawaii Press, 1999.

95. Zhufeng Luo (ed.), Religion under Socialism in China, trans. Donald E. MacInnis and Zheng Xi'an, Armonk, NY: M. E. Sharpe, 1991.

96. Nancy Guy, Peking Opera and Politics in Taiwan, Champaign, IL: University of Illinois Press, 2005.

97. Shi Zhengyan (ed.), Ciji nianjian, 1966-1992 (Ciji yearbook, 1966-1992), Taipei: Ciji wenhua chubanshe, 1993, 53-6.

98. Potter, Belief in Control, 320. 
99. Duckett, The Chinese State's Retreat from Health; Ngok, Social assistance policy; Cook and Lam, China's response to crisis.

100. Hwang, Explaining welfare state adaptation in East Asia; Ko et al., Aging population in East Asia.

101. André Laliberté, The regulation of religious affairs in Taiwan: From state control to laisserfaire?, Journal of Current Chinese Affairs 38(2), 2009: 53-83.

102. Leung, China's religious freedom policy.

103. Fenggang Yang, Religion in China: Survival and Revival under Communist Rule, New York: Oxford University Press, 2011.

104. See André Laliberté, Buddhist charities and China's social policy: An opportunity for alternate civility?, Archives de sciences sociales des religions (Archives of religious studies in social sciences), no. 158, 2012: 95-117.

105. Joseph Tse-Hei Lee, Watchman Nee and the Little Flock movement in Maoist China, Church History 74(1), 2005: 68-96; Joseph Tse-Hei Lee, Christianity in contemporary China: An update, Journal of Church and State 49(2), 2007: 277-304; Joseph Tse-Hei Lee, Politics of faith: Christian activism and the Maoist state in Chaozhou, Guangdong Province, The China Review: Interdisciplinary Journal on Greater China 9(2), 2009: 17-39; Ryan Dunch, Christianity and adaptation to socialism, in Mayfair Mei-Hui Yang (ed.) Chinese Religiosities: Afflictions of Modernity and State Formation, Berkeley, CA: University of California Press, 2008, 155-78; and Carsten T. Vala, Pathways to the pulpit: Leadership training in 'patriotic' and unregistered Chinese Protestant churches, in Yoshiko Ashiwa and David L. Wank (eds) Making Religion, Making the State: The Politics of Religion in Modern China, Stanford, CA: Stanford University Press, 2009, 96-125.

106. I am grateful to an anonymous reviewer for bringing up this issue.

\section{References}

Carpenter, Ted Galen (2012) Ma Ying-jeou's victory provides respite - not resolution in crossStrait tensions. China-US Focus, 25 January. http:/www.chinausfocus.com/peace-security/ ma-ying-jeou $\%$ E2\%80\%99s-victory-provides-respite $\%$ E2\%80\%94not-resolution-incross-strait-tensions/, accessed 18 September 2012.

Carroll, Peter (2006) Between Heaven and Modernity: Reconstructing Suzhou, 1895-1937. Stanford, CA: Stanford University Press.

Chen, Lauren (2000) Lien, Soong look for help from above. Taipei Times, 28 February, 3.

Chiu, Yu-Tzu (2000) Chen meets Cheng Yen to promote 'policy of peace'. Taipei Times, 4 April, 3.

Chong, Gladys Pak Lei (2011) Volunteers as the 'new' model citizens: Governing citizens through soft power. China Information 25(1): 33-59.

Chu, Shulong and Guo, Yuli (2008) Change: Mainland's Taiwan policy. China Security 4(1): $130-6$.

Ciji (2005-2011) Ciji nianjian (Annual reports). http://tw.tzuchi.org/index.php?option=com_conte nt\&view=article\&id=144\&Itemid=199\&lang=zh, accessed 18 September 2012.

Ciji (2010) Sichuan kaochatuan di Tai Ciji xing (Sichuan investigation team arrives in Taiwan to visit Ciji). http://www.tzuchi.org.cn/index.php?option=com_content\&view=artic le \&id=1204:2010-09-22-12-40-36\&catid=56:2009-07-13-09-27-50\&Itemid=162, accessed 4 October 2012.

Ciji (2012) Dalu Ciji: Huabei diqu: Shanxi/Shaanxi (Ciji in mainland China: North China area: Shanxi/Shaanxi). http://www.tzuchi.org.cn/index.php?option=com_content\&view=category\& layout=blog\&id=81\&Itemid=331, accessed 4 October 2012 .

Cook, Sarah, and Lam, Wing (2012) China's response to crisis: What role for social policy? In: Farnsworth, Kevin and Irving, Zoë (eds) Social Policy in Challenging Times: Economic Crisis and Welfare Systems. Bristol: Policy Press, 139-58. 
Deslile, Jacques (2010) Soft power in a hard place: China, Taiwan, cross-Strait relations and U.S. policy. Orbis 54(4) Fall: 494-524.

Ding, Arthur S. and Huang, Paul A. (2011) Taiwan's paradoxical perceptions of the Chinese military: More capable but less threatening? China Perspective, no. 4: 43-51.

Ding, Renjie (1999) Shehui mailuozhong de zhuren xingwei: Taiwan fojiao Ciji gongdehui ge'an yanjiu (Helping behaviour in social context: The case of the Taiwanese Buddhist Ciji Merit Society). Taipei: Lianjing chubanshe.

Duckett, Jane (2011) The Chinese State's Retreat from Health: Policy and the Politics of Retrenchment. New York: Routledge.

Dunch, Ryan (2008) Christianity and adaptation to socialism. In: Yang Mayfair Mei-Hui, (ed.) Chinese Religiosities: Afflictions of Modernity and State Formation. Berkeley: University of California Press, 155-78.

Ford Christopher, A. (2012) 'Occupy Wall Street' and Communist China's Emerging 'Neo-Kong' Discourse of Antidemocratic Legitimacy. Security and Foreign Affairs/Briefing Paper. Washington, DC: Hudson Institute.

French, Howard D. and Wong, Edward (2008) In departure, China invites outside help. New York Times, 16 May. http://www.nytimes.com/2008/05/16/world/asia/16china.html?_r=1, accessed 18 September 2012.

Goossaert, Vincent (2006) 1898: The beginning of the end for Chinese religion? The Journal of Asian Studies 65(2): 307-35.

Goossaert, Vincent and Palmer, David (2011) The Religious Question in Modern China. Chicago: Chicago University Press.

Guy, Nancy (2005) Peking Opera and Politics in Taiwan. Champaign, IL: University of Illinois Press.

He, Fengjiao (ed.) (1996) Taiwan sheng jingwu dang'an huibian: minsu zongjiao pian (Documentary collection of Taiwan's police administration: Folklore and religion). Xindian: Academia Historica.

He, Risheng (ed.) (2006) Ciji 2005 nianjian (Ciji almanac 2005). Hualien: Fojiao Ciji cishan shiye jijinhui.

He, Risheng (ed.) (2007) Ciji 2006 nianjian (Ciji almanac 2006). Hualien: Fojiao Ciji cishan shiye jijinhui.

He, Risheng (ed.) (2008) Ciji 2007 nianjian (Ciji almanac 2007). Hualien: Caituan faren fojiao Ciji cishan shiye jijinhui.

He, Risheng (ed.) (2009) Ciji 2008 nianjian (Ciji almanac 2008). Hualien: Caituan faren fojiao Ciji cishan shiye jijinhui.

Hildebrandt, Timothy (2011) The political economy of social organization registration in China. The China Quarterly, no. 208: 970-89.

Hirono, Miwa (2008) Civilizing Missions: International Religious Agencies in China. New York: Palgrave Macmillan.

Ho, Peter (2007) Embedded activism and political change in a semiauthoritarian context. China Information 21(2): 187-209.

Hsu, S. Philip, Wu, Yu-shan and Zhao, Suisheng (eds) (2011) In Search of China's Development Model: Beyond the Beijing Consensus. New York: Routledge.

Huang, Julia (2009) Charisma and Compassion: Cheng Yen and the Buddhist Tzu Chi Movement. Cambridge, MA: Harvard University Press.

Hwang, Gyu-Jin (2012) Explaining welfare state adaptation in East Asia: The cases of Japan, Korea and Taiwan. Asian Journal of Social Science 40(2): 174-202.

Jets lift life-saving aid materials to Sichuan (2008) The China Post, 16 May. http://www.chinapost.com.tw/taiwan/national/national-news/2008/05/16/156647/p1/Jets-lift.htm, accessed 18 September 2012. 
Jones, Charles Brewer (1999) Buddhism in Taiwan: Religion and the State, 1660-1990. Honolulu: University of Hawaii Press.

Katz, Paul R. and Rubinstein, Murray A. (eds) (2003) Religion and the Formation of Taiwanese Identities. New York: Palgrave Macmillan.

Ko, Chyong-Fang, Oh, Kyeung Mi, and Ogawa, Tetsuo (2007) Aging population in East Asia: Impacts on social protection and social policy reforms in Japan, Korea, and Taiwan. In: Lee, James and Chan, Kah-Wah (eds) The Crisis of Welfare in East Asia. Lanham, MD: Lexington Books, 43-70.

Laliberté, André (2004) The Politics of Buddhist Organizations in Taiwan, 1989-2003: Safeguarding the Faith, Building a Pure Land, Helping the Poor. London: Routledge Curzon.

Laliberté, André (2009) The regulation of religious affairs in Taiwan: From state control to laisserfaire? Journal of Current Chinese Affairs 38(2): 53-83.

Laliberté, André (2012) Buddhist charities and China's social policy: An opportunity for alternate civility? Archives de sciences sociales des religions (Archives of religious studies in social sciences), no. 158: 95-117.

Lee, Chun-yi (2011) Taiwanese Business or Chinese Security Asset: A Changing Pattern of Interaction between Taiwanese Businesses and Chinese Governments. London: Routledge.

Lee, Joseph Tse-Hei (2005) Watchman Nee and the Little Flock movement in Maoist China. Church History 74(1): 68-96.

Lee, Joseph Tse-Hei (2007) Christianity in contemporary China: An update. Journal of Church and State 49(2): 277-304.

Lee, Joseph Tse-Hei (2009) Politics of faith: Christian activism and the Maoist state in Chaozhou, Guangdong Province. The China Review: Interdisciplinary Journal on Greater China 9(2): $17-39$.

Lee honors nun Cheng Yen (1989) Taiwan Today, 11 February. http://taiwantoday.tw/ ct.asp?xItem=7259\&CtNode=122, accessed 18 September 2012.

Leung, Beatrice (2005) China's religious freedom policy: The art of managing religious activity. The China Quarterly, no. 184: 894-915.

Lim, Benjamin Kang (2008) Atheist China gives nod to Taiwan Buddhist group. Reuters, 11 January. http://www.reuters.com/article/2008/03/11/us-china-taiwan-religion-idUSPEK23024220080311, accessed 18 September 2012.

Lim, Benjamin Kang (2010) Taiwan Buddhist charity Tzu Chi sets up shop in atheist China. Reuters, 20 August. http://blogs.reuters.com/faithworld/2010/08/20/taiwan-buddhist-charitytzu-chi-sets-up-shop-in-atheist-china, accessed 4 October 2012.

Lin, Bih-jaw (2004) Yi ruanxing liliang, kaichuang liang'an xinju (Wielding soft power to create a new situation in cross-Strait relations). China Times (Taipei), 12 May, A15.

Lin, Justin Yifu, Cai, Fang, and Li, Zhou (2003) The China Miracle: Development Strategy and Economic Reform. Hong Kong: Chinese University Press.

Luo, Zhufeng (ed.) (1991) Religion under Socialism in China. Trans. MacInnis, Donald E. and Zheng, Xi'an. Armonk, NY: M. E. Sharpe.

Madsen, Richard (2007) Democracy's Dharma: Religious Renaissance and Political Movement in Taiwan. Berkeley, CA: University of California Press.

Ministry of Education, People's Republic of China (2010) Number of schools, external teaching sites and classes in primary schools, 29 December. http://www.moe.edu.cn/publicfiles/business/htmlfiles/moe/s4972/201012/113452.html, accessed 18 September 2012.

Narada Foundation. Compassion empowered. http://narada.nppcn.com/indexSTATICblogname_ narada, accessed 4 October 2012.

Nedostup, Rebecca (2011) Superstitious Regimes: Religion and the Politics of Chinese Modernity. Cambridge, MA: Harvard University Press. 
Neizhengbu (Ministry of the Interior) (1994) Zongjiao lunshu zhuanji. Diyi ji: shehui fuwu pian (Discussions on religion. Vol. 1: Social services). Taipei: Neizhengbu.

Neizhengbu (Ministry of the Interior) (1995) Zongjiao lunshu zhuanji. Di'er ji: shehui jiaohua pian (Discussions on religion. Vol. 2: Social education). Taipei: Neizhengbu.

Ngo, Tak-Wing (1995) Business encirclement of politics: Government-business relations across the Taiwan Strait. China Information, 10(2):1-18.

Ngok, King-lun (2010) Social assistance policy and its impact on social development in China: The case of the Minimum Living Standard Scheme (MLSS). China Journal of Social Work 3(1): 35-52.

Nye, Joseph (1990) Bound to Lead: The Changing Nature of American Power. New York: Basic Books.

Nye, Joseph (2002) The Paradox of American Power: Why the World's Only Superpower Can't Go It Alone. New York: Oxford University Press.

Nye, Joseph (2004) Soft Power: The Means to Success in World Politics. New York: Public Affairs.

O’Neill, Mark (2010) Tzu Chi: Serving with Compassion. Singapore: John Wiley \& Sons.

Pereira, Alexius A. (2003) State Collaboration and Development Strategies in China: The Case of the China-Singapore Suzhou Industrial Park (1992-2002). New York and London: Routledge.

Poon, Shuk-Wah (2011) Negotiating Religion in Modern China: State and Common People in Guangzhou, 1900-1937. Hong Kong: The Chinese University Press.

Potter, Pitman (2003) Belief in control: Regulation of religion in China. The China Quarterly, no. 174: 317-37.

Richardson, James T. \& Edelman, Bryan (2012) State-fostered violence against the Falun Gong in China. In: Lewis, James R. (ed.) Violence and New Religious Movements. New York: Oxford University Press, 379-96.

Rockower, Paul S. (2011) Projecting Taiwan: Taiwan's public diplomacy outreach. Issues \& Studies 47(1): 107-52.

Romberg, Alan D. (2012) After the Taiwan elections: Planning for the future. China Leadership Monitor, no. 37: 1-25.

Roy, Denny (2012) Taiwan: Crisis deferred, but maybe not for long. Asia Pacific Bulletin, no. 145: $1-2$.

Schak, David C. (2011) Protestantism in China: A dilemma for the Party-State. Journal of Current Chinese Affairs 40(2): 71-106.

Schwartz, Jonathan and Shieh, Shawn (eds) (2009) State and Society Responses to Social Welfare Needs in China: Serving the People. London: Routledge.

Shi, Zhengyan (ed.) (1993) Ciji nianjian, 1966-1992 (Ciji yearbook, 1966-1992). Taipei: Ciji wenhua chubanshe.

Shieh, Shawn and Deng, Guosheng (2011) An emerging civil society: The impact of the 2008 Sichuan earthquake on grass-roots associations in China. The China Journal, no. 65: 181-94.

Shih, Teh-cheng, Lin, Xing-ching and Hsieh, Ching-kui (eds) (2000) Great Love across the Taiwan Straits: The Tzu Chi Relief Effort in China, 1991-2000. Taipei: Tzu Chi Cultural Mission Center.

Shlapak, David A., Orletsky, David T., Reid, Toy I., Tanner, Murray Scot, and Wilson, Barry (2009) A Question of Balance: Political Context and Military Aspects of the China-Taiwan Dispute. Santa Monica, CA: RAND Corporation.

Taiwan Ciji bian huanyu: Donglinshanxinfang Gusu (Taiwan's Ciji welcomes Donglin Charity's visit to Suzhou) (2012) Donglin cishan (Donglin charity), 16 April. http://www.donglincs. com/colA_detail.php?wzid=4455\&lbid=251, accessed 18 September 2012.

Thornton, Patricia M. (2009) Crisis and governance: SARS and the resilience of the Chinese body politic. The China Journal, no. 61: 23-48. 
Tong, James W. (2009) Revenge of the Forbidden City: The Suppression of the Falun Gong in China, 1999-2005. New York: Oxford University Press.

Tsai, Lily L. (2007) Accountability without Democracy: Solidary Groups and Public Goods Provision in Rural China. New York: Cambridge University Press.

Tubilewicz, Czeslaw (2012) The politics of compassion: Examining a divided China's humanitarian assistance to Haiti. International Relations of the Asia-Pacific 12(3): 449-81.

Tzu Chi. Global Activities: Asia. http://tw.tzuchi.org/en/index.php?option=com_content\&view=c ategory\&layout=blog\&id=3\&Itemid=204\&lang=en\&limitstart=48, accessed 4 October 2012 .

Vala, Carsten T. (2009) Pathways to the pulpit: Leadership training in 'patriotic' and unregistered Chinese Protestant churches. In: Ashiwa, Yoshiko and Wank, David L (eds) Making Religion, Making the State: The Politics of Religion in Modern China. Stanford, CA: Stanford University Press, 96-125.

Wang, Hongying and Lu, Yeh-chung (2008) The conception of soft power and its policy implications: A comparative study of China and Taiwan. Journal of Contemporary China 17(56): 425-47.

Wang, Tuan-cheng (1999) Ai zai liang'an jian huidang (When love transcends the Taiwan Strait). Taipei: Ciji wenhua zhiyue zhongxin.

Wang, T. Y., Lee, Wei-Chin, and Yu, Ching-Hsin (2011) Taiwan's expansion of international space: Opportunities and challenges. Journal of Contemporary China 20(69): 249-67.

Welle-Strand, Anne, Chen, Pei-Fen, and Ball, Graeme (2011) The Taiwanese economic 'miracle': Continuing? East Asia 28(4): 329-50.

Xiao, Qiang (2012) Taiwan's election on Sina Weibo. China Digital Times, 13 January. http:// chinadigitaltimes.net/2012/01/taiwans-election-on-sina-weibo/, accessed 18 September 2012.

Yang, Fenggang (2011) Religion in China: Survival and Revival under Communist Rule. New York: Oxford University Press.

Yao, Yu-Shuang (2012) Taiwan's Tzu Chi as Engaged Buddhism: Origins, Organization, Appeal and Social Impact. Leiden: Global Oriental/Brill. 